\title{
Environmental Contaminants in Colonial Waterbirds from Great Slave Lake, NWT: Spatial, Temporal and Food-chain Considerations
}

\author{
MARK WAYLAND, ${ }^{1,2}$ KEITH A. HOBSON ${ }^{1,3}$ and JACQUES SIROIS ${ }^{3}$
}

\author{
(Received 27 August 1999; accepted in revised form 31 January 2000)
}

\begin{abstract}
Great Slave Lake in the Northwest Territories, Canada, differs regionally in trophic status and local and regional inputs of contaminants. Spatial and temporal trends in contaminant levels in bioindicator species such as colonial waterbirds could offer insights into the potential for contaminant bioaccumulation in Great Slave Lake. Persistent chlorinated hydrocarbon contaminants, mercury (Hg), and selenium (Se) were examined in herring gull (Larus argentatus) eggs and livers collected from various locations on Great Slave Lake in 1995. Eggs were collected in May and June, and livers in May and August. Also, the relationship between contaminants and trophic level, as inferred from stable-nitrogen isotope analysis $\left(\delta^{15} \mathrm{~N}\right)$, was examined in four colonial waterbird species: herring gull, mew gull (L. canus), Caspian tern (Sterna caspia), and black tern (Chlidonias niger). Finally, the co-accumulation of mercury and selenium was examined in eggs of these birds. There were no differences in chlorinated hydrocarbon concentrations among four sampling sites (colonies). Concentrations did not differ between herring gull adults collected in early May and those collected in early August. Chlorinated hydrocarbon concentrations in eggs of herring gull, mew gull, Caspian tern, and black tern were related to their trophic positions as inferred from their $\delta^{15} \mathrm{~N}$ values in their lipid-free egg yolks. Concentrations in these colonial waterbirds were much higher than those in fish from Great Slave Lake, but lower than those in their conspecifics from the Great Lakes. It is probable that a relatively large proportion of the chlorinated hydrocarbon contaminant load in colonial waterbird eggs on Great Slave Lake results from exposure to and storage of such contaminants at more heavily contaminated wintering and staging areas. This possibility limits the usefulness of colonial waterbirds as indicators of chlorinated hydrocarbon bioaccumulation in Great Slave Lake. Selenium and mercury concentrations in herring gull eggs differed significantly among the four breeding colonies, and concentrations in adults declined between May and August. Selenium and mercury were positively correlated in eggs of all species.
\end{abstract}

Key words: black tern, Caspian tern, Great Slave Lake, herring gull, mew gull, mercury, organochlorines, selenium

RÉSUMÉ. Le Grand lac des Esclaves situé dans les Territoires du Nord-Ouest, au Canada, diffère au niveau régional quant à l'état trophique et à l'apport local et régional de contaminants. Les tendances spatiales et temporelles dans les niveaux de contaminants chez des espèces considérées comme indicateurs biologiques, telles que les oiseaux aquatiques coloniaux, pourraient donner un aperçu du potentiel de bioaccumulation des contaminants dans le Grand lac des Esclaves. On a examiné les contaminants d'hydrocarbures chlorés rémanents, le mercure $(\mathrm{Hg})$ et le sélénium $(\mathrm{Se})$ dans les œufs et le foie du goéland argenté (Larus argentatus) prélevés en 1995 à divers endroits du Grand lac des Esclaves. Les œufs ont été prélevés en mai et juin, et les foies en mai et août. On a en outre étudié le rapport entre les contaminants et l'état trophique, déduit de l'analyse de l'isotope d'azote stable $\left(\delta^{15} \mathrm{~N}\right)$ chez quatre espèces d'oiseaux aquatiques coloniaux: le goéland argenté, le goéland cendré (L. canus), la sterne caspienne (Sterna caspia) et la guifette noire (Chlidonias niger). Pour finir, on a étudié l'accumulation conjointe de mercure et de sélénium dans les œufs de ces oiseaux. Il n'y avait pas de différence dans les concentrations d'hydrocarbures chlorés entre les quatre sites (colonies) échantillonnés. Les concentrations ne différaient pas entre les goélands argentés adultes prélevés début mai et ceux prélevés début août. Les concentrations en hydrocarbures chlorés dans les œufs du goéland argenté, du goéland cendré, de la sterne caspienne et de la guifette noire étaient reliées à leurs positions trophiques déduites des valeurs $\left(\delta^{15} \mathrm{~N}\right)$ trouvées dans le jaune des œufs sans lipides. Les concentrations chez ces oiseaux aquatiques coloniaux étaient beaucoup plus élevées que chez les poissons du Grand lac des Esclaves, mais inférieures à celles trouvées chez leurs congénères des Grands Lacs. Il est probable qu'une proportion relativement importante de la charge de contaminants d'hydrocarbures chlorés dans les œufs des oiseaux aquatiques coloniaux du Grand lac des Esclaves résulte de l'exposition à ces contaminants dans les aires d'hivernage et les points d'escale fortement contaminés, et de leur emmagasinage subséquent. Cette possibilité limite l'utilité des oiseaux aquatiques coloniaux comme indicateurs de bioaccumulation des hydrocarbures chlorés dans le Grand lac des Esclaves. Les concentrations de sélénium et de mercure dans des œufs du goéland argenté diffèrent nettement entre les quatre colonies reproductrices, et les concentrations chez les adultes ont baissé entre mai et août. Le sélénium et le mercure étaient corrélés de façon positive dans les œufs de toutes les espèces.

\footnotetext{
${ }^{1}$ Environment Canada, Prairie and Northern Wildlife Research Centre, 115 Perimeter Road, Saskatoon, Saskatchewan S7N 0X4, Canada

${ }^{2}$ Corresponding author: mark.wayland@ec.gc.ca

${ }^{3}$ Department of Biology, University of Saskatchewan, 112 Science Place, Saskatoon, Saskatchewan S7N 5E2, Canada

(C) The Arctic Institute of North America
} 
Mots clés: guifette noire, sterne caspienne, Grand lac des Esclaves, goéland argenté, goéland cendré, mercure, organochlorés, sélénium

Traduit pour la revue Arctic par Nésida Loyer.

\section{INTRODUCTION}

Great Slave Lake, North America's fifth largest lake, drains an area of northwestern Canada that comprises about $10 \%$ of the nation's landmass. The ongoing industrialization of parts of northwestern Canada has led to concerns that contaminants transported through the Peace, Athabasca, and Slave River systems could be deposited in Great Slave Lake (Muir et al., 1997). There has also been speculation-and some evidence-that volatile organic contaminants and some trace elements have been increasing in northern latitudes as a result of movement of contaminants in air masses (Lockhart et al., 1995; Schindler et al., 1995) and that Great Slave Lake may be a 'sink' for such contaminants. Finally, local domestic and industrial activities could affect contaminant levels in the North Arm of Great Slave Lake (Mudroch et al., 1988). The problem of contamination of northern ecosystems may be further exacerbated if trophic biomagnification between successive steps in the food web is greater in the north than in the south, as has been hypothesized by Schindler et al. (1995).

Great Slave Lake is a diverse ecosystem with three distinct areas that differ in physical and limnological characteristics and potential anthropogenic influences. The East Arm is highly oligotrophic and relatively pristine. The south-central part of the lake is influenced by the Slave River, whereas the North Arm, including Yellowknife Bay, is less oligotrophic than the East Arm and receives contaminant inputs from mining activities in and around Yellowknife.

Colonial waterbirds comprise a group of species that are 'top-predators' in aquatic ecosystems, in that they usually feed on small forage fish species and scavenge. Thus, many colonial waterbirds will accumulate relatively high levels of contaminants that biomagnify through food chains (Government of Canada, 1991). Contaminants may be transferred from body tissues to eggs of laying females. Eggs are high in lipids, providing an excellent matrix for the deposition of lipophilic organic contaminants. Furthermore, colonial nesting habits and fidelity to nesting areas by colonial waterbirds provide a large and predictable source of eggs at a given site, making them easy to collect. These factors, coupled with the view that the collection of eggs for contaminant biomonitoring is more ethical than the collection of adult animals, make colonial waterbirds effective and socially acceptable indicator species.

Great Slave Lake is an important breeding area for colonial waterbirds in northwestern Canada. Ten species breed there: five gulls, four terns, and the parasitic jaeger
Stercorarius parasiticus. Over 6000 nests were located in comprehensive surveys during the late 1980s and early 1990s (Sirois et al., 1995).

A recent development in the field of contaminant modeling and analysis is the use of naturally occurring stable isotopes of nitrogen $\left(\delta^{15} \mathrm{~N}\right)$ as a means of determining trophic level (reviewed by Kidd, 1998). This technique is based on the fact that stable-nitrogen isotope ratios in food webs show a stepwise increase with trophic level. Relative trophic position can thus be inferred from $\delta^{15} \mathrm{~N}$ values in consumers and their eggs (Jarman et al., 1996). Stable-nitrogen isotope data for all colonial waterbird species and for their supporting food chains indicate that contaminant biomagnification potential differs widely among bird species (Hobson et al., 2000). Thus certain species should have higher levels of exposure to bioaccumulable contaminants, making them more sensitive indicators of contaminant exposure, all other factors being equal.

The objective of this study was to provide basic information about the distribution and bioaccumulation of contaminants in four species of colonial waterbirds from Great Slave Lake. We examine spatial and seasonal differences in contaminants in herring gulls (Larus argentatus) from Great Slave Lake and describe the relationship between trophic position and contaminant levels in herring gulls, mew gulls (L. canus), Caspian tern (Sterna caspia), and black tern (Chlidonias niger). Also, we determined whether selenium and mercury were correlated in eggs of these species. We examined this relationship because selenium is presumed to reduce mercury toxicity in birds (Scheuhammer, 1987), and several investigators (e.g., Norheim, 1987; Henny et al., 1991) have reported the coaccumulation of these two elements in livers of birds.

\section{METHODS}

\section{Collections}

Samples were collected during the spring and summer of 1995. Freshly laid herring gull eggs were collected from four nesting colonies at different locations on Great Slave Lake: 1) Yellowknife Bay in the North Arm; 2) Francois Bay in the East Arm; 3) Egg Island, near the Slave River Delta; and 4) Brabant Island, near the head of the Mackenzie River (Fig. 1). Whole eggs, including shells, were placed in solvent-rinsed glass jars and frozen soon after collection.

We collected adult herring gulls in the spring during the nesting period and again in August near the end of the 


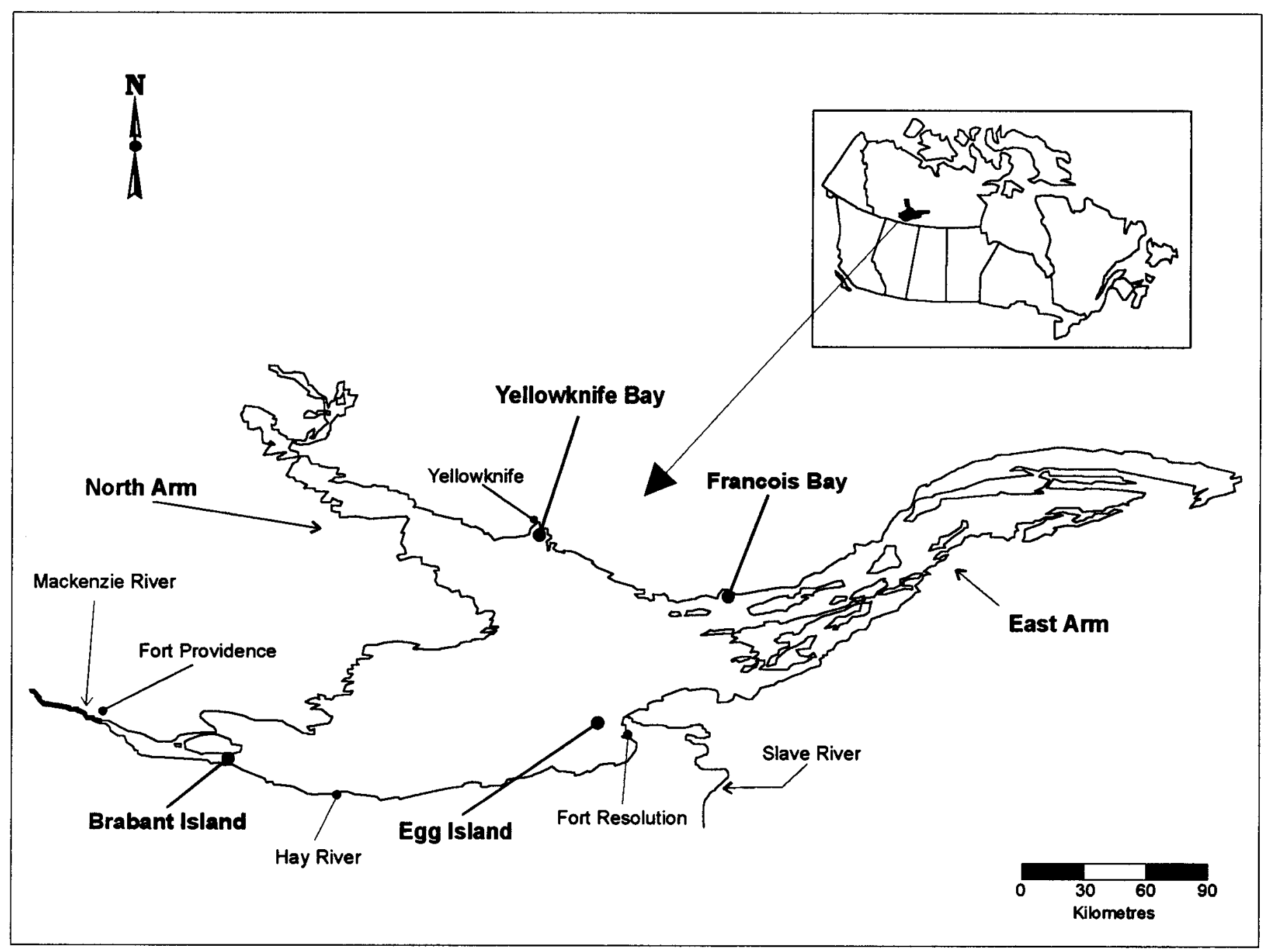

FIG. 1. Map of Great Slave Lake showing the four sampling sites: Yellowknife Bay (North Arm), Francois Bay, Egg Island, and Brabant Island.

brood-rearing period. These collections were made in Yellowknife Bay. Following collection, livers were removed, placed in acid- and acetone-washed glassware, and frozen.

Eggs of mew gull, Caspian tern, and black tern were collected in the North Arm, placed in solvent-rinsed jars, and frozen.

\section{Contaminant Analyses}

Samples were stored at $-20^{\circ} \mathrm{C}$ until analysis. Herring gull eggs and tissues were analyzed individually. Eggs of other species were analyzed in pools, consisting of 3-4 eggs per pooled sample.

Methods for analyzing organochlorine pesticides, chlorobenzenes, and PCBs are based on those described by Norstrom et al. (1988). These methods provide results for 56 organochlorine compounds. Chemical analysis was done by gas chromatography, using a Hewlett-Packard 5890 Series 2 Plus GC equipped with a Hewlett-Packard 7673A auto injector and DB5 column (dimensions: $0.25 \mathrm{~mm}$ internal diameter $\times 60 \mathrm{~m}$ length). The detection limit was $0.0001 \mu \mathrm{g} / \mathrm{g}$, wet weight. Analysis of standard reference materials and duplicates indicated that, for the major chlorinated hydrocarbon contaminants, the standard deviation averaged $3 \%$ of the mean and ranged between 0 and $10 \%$ of the mean. Recoveries ranged from 77 to $130 \%$. Values are reported on a wet weight basis.

Mercury in eggs was analyzed by cold vapour atomic absorption spectrometry, using a LDC Analytical UV detector (fixed wavelength mercury monitor). Recovery ranged from 95 to $102 \%$ for the standard reference material (DORM-1 from the National Research Council) and from 100 to $103 \%$ for method spikes. Analysis of duplicates indicated that the standard deviation was $\pm 3 \%$ of the mean value. The detection limit was approximately 0.04 $\mathrm{mg} / \mathrm{kg}$ dry weight.

Selenium in eggs was analyzed using a Sciex Perkin Elmer Elan 5000 ICP-MS in accordance with EPA method 200.8 (USEPA, 1998). Standards were analyzed, and recovery ranged from 80 to $109 \%$ (mean $=97 \%$ ). Duplicate analyses indicated that the standard deviation was $\pm 13 \%$ of the mean. The detection limit was $2 \mathrm{mg} / \mathrm{kg}$ dry weight.

Mercury in liver was analyzed by cold vapour atomic absorption spectrometry, using a 3030 Perkin Elmer atomic 
absorption spectrometer equipped with a Varian VGA-76 hydride generator and a Varian PSC-55 autosampler. Recovery of standard reference materials ranged from 97 to $98 \%$, and analytical spike recovery ranged from 98 to $102 \%$. The detection limit was $0.10 \mathrm{mg} / \mathrm{kg}$ dry weight.

Selenium in livers was analyzed by graphite furnace AAS, using a Perkin-Elmer 3030b spectrometer equipped with an HGA-300 graphite furnace and an AS-40 autosampler. Argon was used as the purge gas. Recovery of standard reference materials ranged from 95 to $97 \%$. The detection limit was $0.20 \mathrm{mg} / \mathrm{kg}$ dry weight.

\section{Stable Isotope Analysis}

Stable-nitrogen isotope assays were performed on $1 \mathrm{mg}$ samples of dried, homogenized, and lipid-free egg yolks, following methods described by Jarman et al. (1996). Briefly, approximately $1 \mathrm{mg}$ of powdered sample was loaded into tin cups and combusted at $1800^{\circ} \mathrm{C}$ in a RoboPrep elemental analyzer. We analyzed the resultant gas with a Europa 20:20 continuous-flow isotope ratio mass spectrometer (CFIRMS), with every five unknowns separated by two laboratory standards. Stable isotope concentrations were expressed in $\delta$ notation as the deviation from standards in parts per thousand $(\%)$, according to the following equation:

$$
\delta^{15} \mathrm{~N}=\left[\left(\mathrm{R}_{\text {sample }} / \mathrm{R}_{\text {standard }}\right)-1\right] \times 1000,
$$

where $R$ is the corresponding ratio ${ }^{15} \mathrm{~N} /{ }^{14} \mathrm{~N}$. The $\mathrm{R}_{\text {standard }}$ value for ${ }^{15} \mathrm{~N}$ is based on atmospheric $\mathrm{N}_{2}$ (AIR). Replicate measurements of internal laboratory standards (albumen) indicate measurement errors of $0.3 \%$ for stable nitrogen isotope measurements.

\section{Statistics}

In the results, the sum of PCBs is the sum of the concentrations of $39 \mathrm{PCB}$ congeners or congener combinations. The sum of chlordanes is the sum of six compounds representing technical chlordane and its metabolites, and the sum of DDT is the sum of three compounds representing DDT and its metabolites. We used factor 1 from a factor analysis (SAS Institute, 1988) to summarize the data on the 56 chlorinated hydrocarbon compounds.

We used multivariate analysis of variance (MANOVA) to test for statistical differences in chlorinated hydrocarbon contaminant concentrations among different breeding colonies, between herring gulls sampled in May and in August, and among the four water bird species. MANOVAs included the following dependent variables: sum of PCBs, sum of chlordanes, sum of DDTs, and factor 1 scores. Following significant MANOVAs, univariate analysis of variance (ANOVA) was used to determine which group of contaminants differed among colonies, sampling times, or species. Mercury and selenium data were analyzed separately using ANOVA. A posteriori multiple comparisons were done using the Tukey-Kramer method. Data were log-transformed prior to analysis. Statistical analyses were done using SAS 6.03 (SAS Institute, 1988).

\section{RESULTS}

\section{Spatial Analysis of Herring Gull Eggs}

A factor analysis of all the chlorinated hydrocarbon contaminant data produced a variable, Factor 1, that accounted for $47 \%$ of the overall variance in that data. Factor 1 represented strongly the following contaminants, which commonly occur at high concentrations in biota: DDE, mirex, oxychlordane, cis-nonachlor, and several highly chlorinated and persistent PCB congeners (e.g., PCB105, PCB110, PCB118, PCB138, PCB153, and PCB180) (Table 1). A multivariate analysis of variance on the sum of DDT and its metabolites (sDDT), the sum of PCB congeners (sPCB), the sum of chlordane compounds (sCHLOR), and Factor 1 scores (MANOVA: $p=0.22$ ) showed no significant difference among sites in mean chlorinated hydrocarbon contaminant concentration. This similarity is reflected by the high degree of similarity among sites in their chlorinated hydrocarbon contaminant concentrations in eggs (Table 2). Mean selenium concentrations ranged from $1.8 \mathrm{mg} / \mathrm{kg}$ at Yellowknife Bay to $3.9 \mathrm{mg} / \mathrm{kg}$ at Brabant Island (Table 2). Selenium concentrations differed significantly among all sites except for Egg Island and Francois Bay (Tukey-Kramer a posteriori multiple comparison: $p<0.05$, following overall significant ANOVA: $p<0.001)$. Mean total mercury concentrations ranged from 0.3 to $1.1 \mathrm{mg} / \mathrm{kg}$ (Table 2). Eggs from Francois Bay had significantly higher concentrations of mercury than those from Egg Island and Yellowknife Bay, while eggs from Brabant Island had significantly higher concentrations than those from Yellowknife Bay (Tukey-Kramer a posteriori multiple comparison: $p<0.05$, following a significant ANOVA: $p<0.0001)$.

\section{Seasonal Analysis of Herring Gull Livers}

A factor analysis of all the chlorinated hydrocarbon contaminant data produced a variable, Factor 1, which accounted for $46 \%$ of the overall variance in that data. Factor 1 represented strongly the following contaminants that occur at relatively high concentrations in biota: DDE, mirex, oxychlordane, and several highly chlorinated PCB congeners such as PCB99, PCB105, PCB118, PCB138 and PCB153 (Table 1). There was no significant difference (MANOVA: $p=0.98$ ) in chlorinated hydrocarbon contaminants in livers of herring gulls between May and August samples, although there was an overall trend towards a slight decrease in concentrations between these two sampling periods (Table 3 ).

Significant declines were noted for selenium $(p=0.002)$ and total mercury $(p=0.02)$ in herring gull livers between May and August. Concentrations of these trace elements 
TABLE 1. Factor 1 loadings and proportion of variance explained based on principal components analysis of chlorinated hydrocarbon contaminant data in herring gull eggs and livers and multispecies eggs. Only compounds with a Factor 1 loading $\geq 0.8$ for at least one of the three analyses are shown.

\begin{tabular}{|c|c|c|c|}
\hline $\begin{array}{l}\text { Herrin } \\
F_{c}\end{array}$ & $\begin{array}{l}\text { Gull Eggs } \\
\text { ictor } 1\end{array}$ & $\begin{array}{l}\text { Herring Gull Liver } \\
\text { Factor } 1\end{array}$ & $\begin{array}{c}\text { Multispecies Eggs } \\
\text { Factor } 1\end{array}$ \\
\hline & 0.885 & 0.787 & 0.546 \\
\hline $\begin{array}{l}\text { pp'-DDE } \\
\text { photo-Mirex }\end{array}$ & 0.833 & 0.841 & 0.895 \\
\hline photo-Mirex & 0.839 & -0.076 & -0.267 \\
\hline Mirex & 0.855 & 0.958 & 0.662 \\
\hline oxy-Chlordane & 0.842 & 0.859 & 0.494 \\
\hline cis-Nonachlor & 0.873 & 0.756 & 0.768 \\
\hline РCB 60 & 0.764 & -0.053 & 0.872 \\
\hline РCB 99 & 0.880 & 0.976 & 0.944 \\
\hline PCB 105 & 0.939 & 0.952 & 0.873 \\
\hline PCB 110 & 0.806 & 0.738 & 0.849 \\
\hline PCB 118 & 0.852 & 0.970 & 0.935 \\
\hline PCB 129 & 0.738 & 0.896 & 0.854 \\
\hline PCB 138 & 0.975 & 0.944 & 0.966 \\
\hline PCB 146 & 0.972 & 0.960 & 0.971 \\
\hline PCB 153 & 0.972 & 0.902 & 0.961 \\
\hline PCB 158 & 0.799 & 0.951 & 0.876 \\
\hline PCB 171 & 0.858 & 0.814 & 0.941 \\
\hline PCB 172 & 0.959 & 0.826 & 0.962 \\
\hline PCB 174 & 0.654 & 0.341 & 0.576 \\
\hline PCB 180 & 0.962 & 0.598 & 0.953 \\
\hline PCB 183 & 0.977 & 0.896 & 0.962 \\
\hline PCB 194 & 0.840 & 0.660 & 0.929 \\
\hline PCB 195 & 0.559 & 0.480 & 0.843 \\
\hline PCB 200 & 0.585 & 0.831 & 0.700 \\
\hline PCB 201 & 0.688 & 0.694 & 0.844 \\
\hline PCB 203 & 0.774 & 0.731 & 0.924 \\
\hline PCB 66/95 & 0.947 & 0.728 & 0.966 \\
\hline PCB $182 / 187$ & 0.967 & 0.874 & 0.945 \\
\hline РCB 170/190 & 0.969 & 0.825 & 0.942 \\
\hline $\begin{array}{l}\text { Proportion of } \\
\quad \text { variance explained }\end{array}$ & 0.4699 & 0.4649 & 0.6131 \\
\hline
\end{tabular}

were approximately two to three times greater in the May sample than in the August sample (Table 3).

\section{Contaminant/Trophic Level Relationships}

Stable-nitrogen isotope analysis of lipid-free egg yolk suggested a gradient in trophic levels of laying females, with black terns somewhat lower than herring gulls and Caspian terns, which were, in turn, lower than mew gulls (Fig. 2). Mew gulls had significantly higher $\delta^{15} \mathrm{~N}$ values than herring gulls and black terns $(p<0.05)$.

A factor analysis of all the chlorinated hydrocarbon data produced a variable, Factor 1, that explained $61 \%$ of the overall variance in the contaminant data for all herring gull, mew gull, Caspian tern, and black tern egg samples. Factor 1 represented strongly several common compounds that are known to occur at relatively high concentrations in biota (e.g., DDE, PCB99, PCB105, PCB118, PCB153, PCB180). Chlorinated hydrocarbon contaminants differed among the four species (MANOVA: $p<0.0001$ ). In general, concentrations of contaminants and Factor 1 scores in Caspian tern and mew gull eggs were significantly higher than those in herring gull eggs $(p<0.05)$, which in turn were significantly higher $(p<0.05)$ than those in black tern eggs (Fig. 2). There was a close correspondence between contaminant concentrations in eggs and $\delta^{15} \mathrm{~N}$ values, suggesting a relationship between contaminant concentrations and trophic level of laying females.

\section{Selenium/Mercury Correlation in Eggs}

Selenium and mercury concentrations, expressed as log-transformed molar values, were positively and significantly correlated in eggs of the four species $\left(r_{\text {pearson }}=0.54\right.$, $p=0.003$, Fig. 3 ). The molar ratio of selenium to mercury was approximately 11:1.

\section{DISCUSSION}

\section{Spatial Variability in Contaminants in Herring Gull Eggs}

We found no evidence of spatial variability in chlorinated hydrocarbon contaminant levels in herring gull eggs from Great Slave Lake. This finding contrasts with that of Evans (1996, 1997), who reported spatial variability in organochlorine contaminants in fish, invertebrate, and sediment samples from Great Slave Lake. The absence of among-site differences may be the result of (1) small sample sizes, resulting in low statistical power; (2) broad feeding ranges of gulls on Great Slave Lake, so that their nesting location did not reflect their feeding location; or (3) contaminants in the eggs that originated from feeding locations on migration or wintering areas. We did not calculate statistical power in this study, but it is safe to assume that the small sample $(n=19)$, coupled with the wide variation in contaminant concentrations (Table 2), would have resulted in a low capability to detect a significant difference among sites, even if differences were quite large.

It is unlikely that herring gulls had feeding ranges large enough for overlap with gulls from different colonies. Colonies were separated by $125-225 \mathrm{~km}$, distances which should have precluded extensive mixing, especially if gulls restrict their feeding activities to a localized area around their nesting colony from the time of their arrival at Great Slave Lake in early spring until the end of the nesting period. Such foraging patterns have been documented in gulls on the Great Lakes (Fox et al., 1990), and Morris and Black (1980) reported maximum foraging distances of $30 \mathrm{~km}$ from the colony.

Another possible explanation for our inability to detect spatial variability in contaminants in herring gull eggs is that a large proportion of the chlorinated hydrocarbon contaminants in their eggs is accumulated on the wintering grounds or during migration. Many lipophilic chlorinated hydrocarbon contaminants are stored in tissues for long periods before they are deposited in eggs. For example, half-lives in herring gull tissues are in the range of $200-$ 300 days for DDE (Norstrom et al., 1986), 340 days for oxychlordane, and 136 days for dieldrin (Clark et al., 
TABLE 2. Chlorinated hydrocarbon contaminants $(\mu \mathrm{g} / \mathrm{g}$, wet wt), mercury and selenium $(\mu \mathrm{g} / \mathrm{g}$, dry wt) in eggs, and Factor $1 \mathrm{scores}$ from factor analysis of all chlorinated hydrocarbon data for eggs .

\begin{tabular}{|c|c|c|c|c|c|c|c|c|c|}
\hline Species $^{1}$ & Location & Sample No. & $\Sigma$ DDTs & $\Sigma$ Chlordanes & $\Sigma \mathrm{PCBs}$ & Factor $1^{2}$ & Factor $1^{3}$ & $\mathrm{Se}$ & $\mathrm{Hg}$ \\
\hline \multirow[t]{19}{*}{ HEGU } & \multirow[t]{4}{*}{ Brabant Island } & L97-79008 & 0.550 & 0.052 & 0.434 & 1.133 & 0.757 & 3.846 & .885 \\
\hline & & L97-79009 & 0.323 & 0.048 & 0.187 & -0.796 & -0.473 & 4.348 & 1.000 \\
\hline & & L97-79010 & 0.307 & 0.048 & 0.190 & -0.793 & -0.448 & 3.600 & 0.600 \\
\hline & & L97-79011 & 0.220 & 0.026 & 0.136 & -1.573 & -0.900 & 3.913 & 0.696 \\
\hline & \multirow[t]{5}{*}{ Francois Bay } & L97-79012 & 0.209 & 0.023 & 0.130 & -1.661 & -1.039 & 2.273 & 0.682 \\
\hline & & L97-79013 & 0.419 & 0.073 & 0.203 & -0.208 & -0.201 & 2.174 & 0.870 \\
\hline & & L97-79014 & 0.637 & 0.059 & 0.457 & 1.108 & 0.658 & 2.727 & 1.273 \\
\hline & & L97-79015 & 2.003 & 0.065 & 0.462 & 1.144 & 0.596 & 3.043 & 1.043 \\
\hline & & L97-79016 & 1.098 & 0.085 & 0.399 & 1.036 & 0.558 & 2.500 & 2.042 \\
\hline & \multirow[t]{5}{*}{ Egg Island } & L97-79017 & 0.305 & 0.075 & 0.350 & 0.755 & 0.327 & 2.500 & 0.363 \\
\hline & & L97-79018 & 0.803 & 0.108 & 0.375 & 0.769 & 0.473 & 2.500 & 0.458 \\
\hline & & L97-79019 & 0.585 & 0.052 & 0.257 & 0.053 & -0.022 & 2.400 & 0.480 \\
\hline & & L97-79020 & 0.500 & 0.054 & 0.300 & 0.370 & 0.154 & 2.609 & 0.430 \\
\hline & & L97-79021 & 0.561 & 0.062 & 0.364 & 0.928 & 0.515 & 2.083 & 0.625 \\
\hline & \multirow[t]{5}{*}{ Yellowknife Bay } & L97-79022 & 0.378 & 0.024 & 0.215 & -0.741 & -0.488 & 1.364 & 0.273 \\
\hline & & L97-79023 & 0.186 & 0.020 & 0.141 & -1.502 & -0.831 & 1.500 & 0.230 \\
\hline & & L97-79024 & 0.211 & 0.021 & 0.187 & -1.021 & -0.435 & 1.818 & 0.268 \\
\hline & & L97-79025 & 0.474 & 0.035 & 0.319 & 0.329 & 0.120 & 2.273 & 0.345 \\
\hline & & L97-79026 & 0.771 & 0.041 & 0.359 & 0.671 & 0.396 & 2.174 & 0.435 \\
\hline \multirow[t]{3}{*}{ BLTE } & \multirow[t]{3}{*}{ North Arm } & L99-82114 & 0.086 & 0.009 & 0.028 & - & -2.856 & 1.957 & 0.348 \\
\hline & & L99-82115 & 0.090 & 0.008 & 0.088 & - & -1.794 & 2.000 & 0.435 \\
\hline & & L99-82116 & 0.164 & 0.012 & 0.139 & - & -1.262 & 1.217 & 0.478 \\
\hline \multirow[t]{3}{*}{ CATE } & & L99-82117 & 1.501 & 0.045 & 0.676 & - & 1.309 & 2.273 & 1.136 \\
\hline & & L99-82118 & 1.945 & 0.016 & 0.426 & - & 0.558 & 2.182 & 1.273 \\
\hline & & L99-82119 & 1.898 & 0.046 & 1.257 & - & 1.967 & 2.091 & 1.045 \\
\hline \multirow[t]{3}{*}{ MEGU } & & L99-82120 & 1.185 & 0.041 & 0.545 & - & 0.648 & 1.565 & 0.391 \\
\hline & & L99-82121 & 1.285 & 0.045 & 0.922 & - & 1.251 & 1.870 & 0.261 \\
\hline & & L99-82122 & 1.776 & 0.068 & 0.418 & - & 0.464 & 1.435 & 0.348 \\
\hline
\end{tabular}

${ }^{1}$ HEGU = herring gull; BLTE = black tern; CATE = Caspian tern; MEGU = mew gull.

${ }^{2}$ Factor 1 scores from factor analysis examining spatial relationships of all chlorinated hydrocarbon data in HEGU eggs.

${ }^{3}$ Factor 1 scores from factor analysis comparing chlorinated hydrocarbon levels in HEGU, BLTE, CATE, and MEGU eggs.

TABLE 3. Chlorinated hydrocarbon contaminants $(\mu \mathrm{g} / \mathrm{g}$, wet wt), mercury and selenium $(\mu \mathrm{g} / \mathrm{g}$, dry wt) in livers of adult herring gulls collected in the North Arm, and Factor 1 scores from factor analysis of all chlorinated hydrocarbon data in their livers.

\begin{tabular}{|c|c|c|c|c|c|c|c|}
\hline Time Period & Sample No. & $\Sigma$ DDTs & $\Sigma$ Chlordanes & $\Sigma \mathrm{PCBs}$ & Factor $1^{1}$ & $\mathrm{Se}$ & $\mathrm{Hg}$ \\
\hline \multirow[t]{5}{*}{ May } & L97-79094 & 1.230 & 0.038 & 0.538 & 1.348 & 6.20 & 1.79 \\
\hline & L97-79095 & 0.318 & 0.040 & 0.155 & -0.906 & 8.71 & 2.09 \\
\hline & L97-79096 & 2.108 & 0.030 & 0.355 & 0.971 & 15.89 & 6.81 \\
\hline & L97-79097 & 0.303 & 0.025 & 0.195 & -0.589 & 6.73 & 5.56 \\
\hline & L97-79098 & 0.315 & 0.018 & 0.244 & -0.284 & 10.50 & 3.82 \\
\hline \multirow[t]{5}{*}{ August } & L97-79099 & 0.587 & 0.025 & 0.327 & 0.323 & 2.73 & 1.18 \\
\hline & L97-79100 & 0.883 & 0.078 & 0.444 & 1.627 & 3.72 & 2.04 \\
\hline & L97-79101 & 0.499 & 0.015 & 0.211 & -0.491 & 2.05 & 0.86 \\
\hline & L97-79102 & 0.370 & 0.017 & 0.167 & -1.023 & 4.20 & 1.59 \\
\hline & L97-79103 & 0.359 & 0.014 & 0.214 & -0.976 & 4.44 & 1.61 \\
\hline
\end{tabular}

${ }^{1}$ Factor 1 scores from factor analysis examining seasonal relationships in HEGU livers.

1987). These numbers suggest that these contaminants may be accumulated and stored over a long period of time prior to deposition in eggs. In support of this contention, Norstrom et al. (1986) detected ${ }^{14} \mathrm{C}$-labeled DDE in eggs of herring gulls that had been dosed with the labeled compound almost one year before egg-laying. Weseloh et al. (1994) found that herring gulls returning to breed at different colonies on Lake Superior had contaminant profiles in their eggs that reflected, in part, their wintering distributions on the lower Great Lakes. In addition, Hebert et al. (1997) found that some of the year-to-year variability of organochlorine levels in herring gull eggs from Lake Ontario was explained by winter weather, which was hypothesized to influence feeding behaviour and dietary accumulation of contaminants during winter months. Their findings suggest that at least some of the organochlorine concentrations in gull eggs are the result of accumulation during the winter. We suspect this phenomenon also applies to gulls at Great Slave Lake because of the relatively short period of time between their arrival there and the onset of egg-laying (Sirois et al., 1995). Additional contributing factors are the long tissue retention time of many 

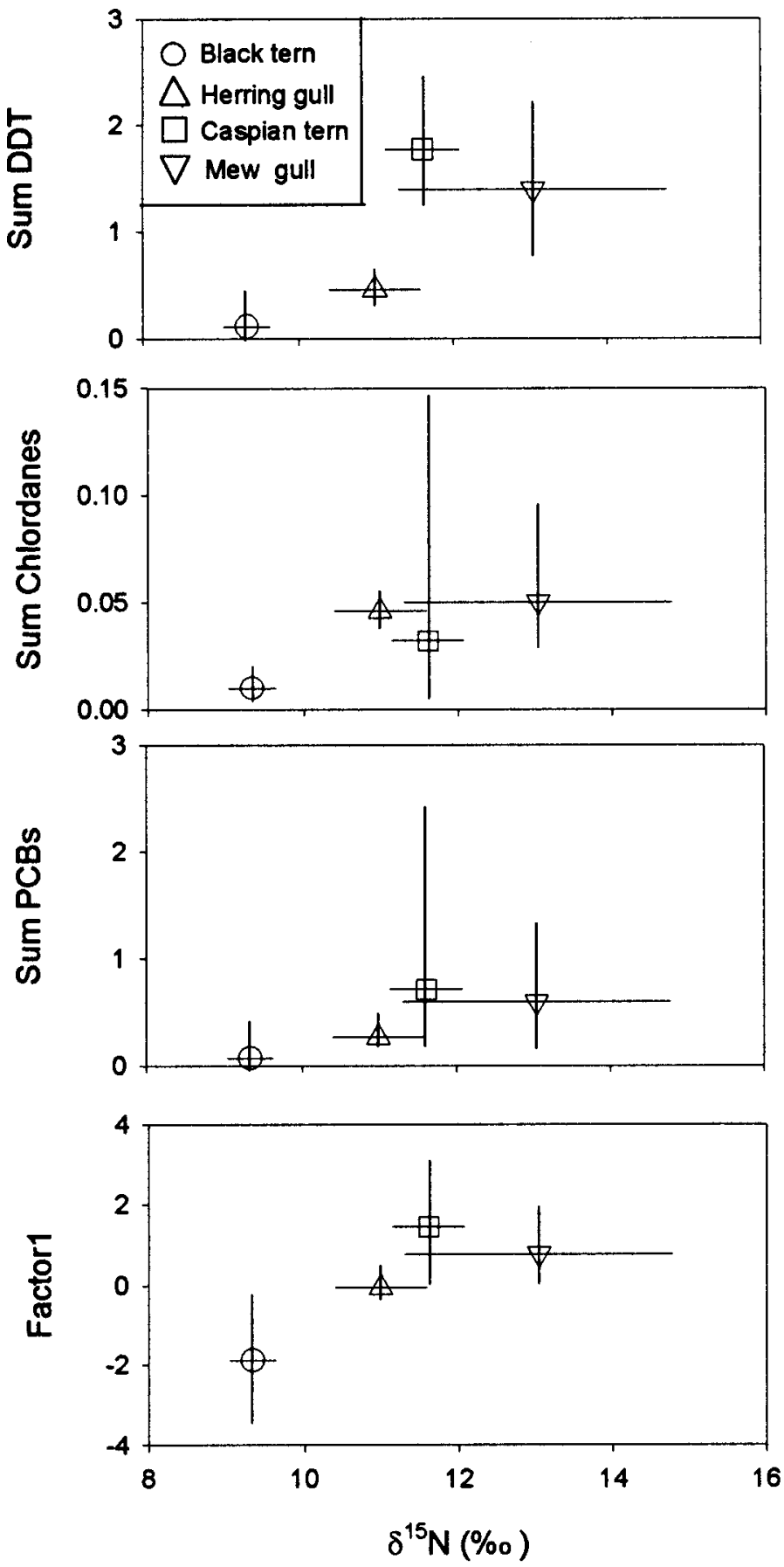

FIG. 2. Means (95\%CL) for chlorinated hydrocarbons ( $\mu \mathrm{g} / \mathrm{g}$, wet weight) and factor 1 scores from factor analysis of chlorinated hydrocarbons in eggs and $\delta^{15} \mathrm{~N}$ ratios (\%o) in lipid-free egg yolks of black tern, mew gull, herring gull, and Caspian tern.

chlorinated hydrocarbons, their high fat-solubility, and the deposition of lipids in eggs (Hobson et al., 2000).

Selenium and mercury concentrations in herring gull eggs on Great Slave Lake showed evidence of spatial variability. Selenium is an essential trace element that can become toxic if excessive exposure occurs (Ohlendorf et al., 1988). It has a relatively short biological half-life, on the order of one to three weeks in mallards (Anas platyrhynchos) (Heinz et al., 1990). It also bioaccumulates

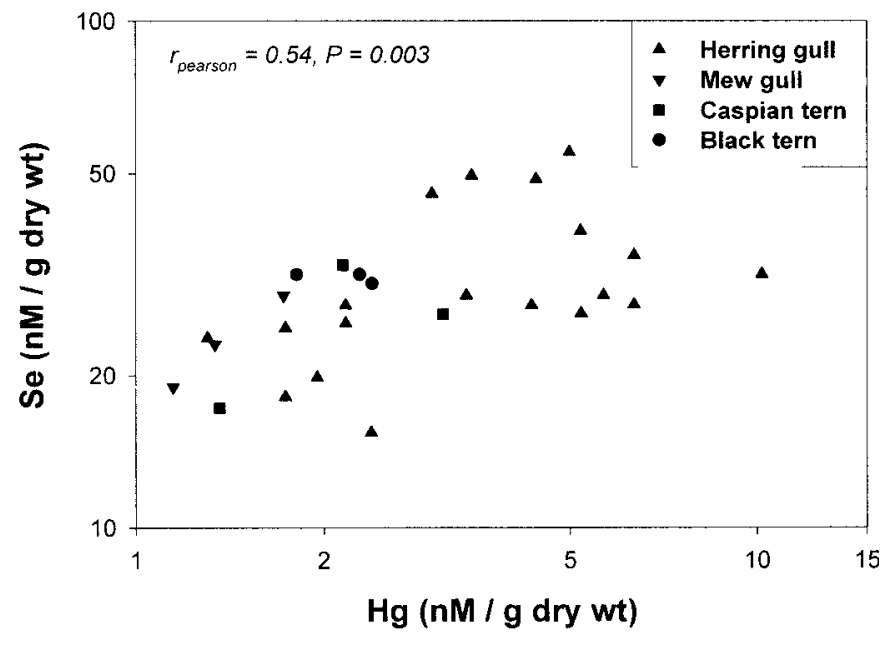

FIG. 3. Plot of total mercury and selenium (nM/g, dry weight) concentrations in eggs of four colonial waterbird species.

through food chains (Lemly, 1997). Its short biological half-life suggests that the Great Slave Lake ecosystem is the likely source of selenium in herring gull eggs. However, it is unclear whether the spatial differences found in this study reflect differences in selenium levels in the food chain or differences in the composition of the food chain (and thus of trophic relationships) among the sites. In any event, selenium levels in herring gull eggs in this study were well below the levels associated with high rates of embryonic mortality in birds (Lemly, 1995).

Low levels of mercury were detected in herring gull eggs, and differences were noted among sites. Mercury has an affinity for sulfhydryl proteins, and its biological half-life in birds is two to three months (Scheuhammer, 1987). These facts, coupled with the use of stored proteins for egg formation in larids (Bolton et al., 1992), suggest that mercury concentrations in herring gull eggs in Great Slave Lake may reflect dietary exposure to mercury on wintering areas, during migration, and at Great Slave Lake. Thus, it is unclear whether the spatial variation in mercury in herring gull eggs found in this study truly reflected among-site differences in mercury in the lake as a whole. This variation could be an artifact of some other phenomenon: for example, among-site differences in food chain structure and thus bioaccumulation potential (Atwell et al., 1998), or among-site differences in mercury accumulation by the birds during winter and spring, before their arrival at Great Slave Lake.

\section{Seasonal Changes in Contaminants}

There was no evidence of a decline in chlorinated hydrocarbon contaminant concentrations in adult herring gulls from Great Slave Lake between the prelaying and postbreeding periods (from mid-May to early August). This was somewhat surprising, since at least one of five May samples and three of five August samples were females. Females are known to excrete lipophilic chlorinated contaminants into eggs each spring, thus reducing their 
overall contaminant burdens (Norstrom et al., 1986). However, as mentioned above, the small number of gulls likely reduced the probability of detecting a significant difference. Furthermore, lipid content of birds is known to vary widely during the year, and this variability may produce corresponding changes in lipophilic organic contaminant concentrations in their tissues (Norstrom et al., 1986). Elliott et al. (1996) reported peak DDE and PCB concentrations in bald eagles during spring and very slight declines from spring to mid-summer. They suggested that this pattern reflected the pattern of fat mobilization in spring followed by fat deposition later in the summer. Thus, variability in concentrations of contaminants in the livers of herring gulls from Great Slave Lake will reflect not only actual differences in exposure, but also differences in the size of the lipid pool and differences among tissues in partitioning. Thus, to truly understand whether contaminants decline in herring gulls on Great Slave Lake during their summer residency there, it would be better to perform whole-body analysis, so that the total burden of different contaminants could be determined in the animal as a whole (Ankley et al., 1993). Unfortunately, whole bodies were not available for analysis in this study.

In contrast to the chlorinated hydrocarbons, selenium and mercury decreased significantly in birds over the breeding season. The decrease in selenium is consistent with spring movement of the birds from a marine to a freshwater environment, coupled with the rapid depuration of selenium from tissues (Heinz et al., 1990). Winter and early spring use of marine habitats was inferred from stable-carbon and nitrogen isotopic data from colonial waterbirds on Great Slave Lake by Hobson et al. (2000). Selenium levels tend to be higher in marine biota than in freshwater biota from nonpolluted areas (Eisler, 1985).

Mercury in tissues of birds also decreased significantly from May to August, perhaps signifying that herring gulls 'cleanse' themselves of mercury during their summer residency on Great Slave Lake. For females, a small portion of the mercury was probably excreted in eggs (Heinz, 1979). More importantly, the growth of new feathers was probably an important factor in reducing internal body burdens of mercury. The process of feather moult is associated with a major redistribution of mercury from soft tissues to feathers (Braune and Gaskin, 1987). In eastern North America, herring gulls moult their primary feathers from late July through September, and the beginning of the moult usually coincides with hatching (Pierotti and Good, 1994). Thus, primary feather moult may have begun and progressed significantly between the May and August samples, suggesting that moult may have accounted for some of the observed seasonal decline in hepatic mercury in herring gulls on Great Slave Lake.

\section{Contaminant/Trophic Relationships}

Several previous studies have demonstrated a relationship between trophic structure, as measured using $\delta^{15} \mathrm{~N}$ analyses, and persistent chlorinated hydrocarbon and mercury concentrations in food webs (Spies et al., 1989; Broman et al., 1992; Kidd et al., 1995; Jarman et al., 1996; Atwell et al., 1998). In this study, trophic level and chlorinated hydrocarbon concentrations were lowest in black terns, followed by herring gulls. Mew gulls and Caspian terns with higher $\delta^{15} \mathrm{~N}$ values of their eggs also contained chlorinated hydrocarbon concentrations higher than those found in herring gull and black tern eggs. The fact that Caspian terns feed nearly exclusively on fish (Ewins et al., 1994) accounts for the relatively high $\delta^{15} \mathrm{~N}$ values of and contaminant levels in their eggs. Somewhat more surprising were the high contaminant levels and stable isotopeinferred trophic levels of mew gulls, which feed on insects, crayfish, and small fish (Terres, 1980; Vermeer and DeVito, 1986). Herring gulls are generalist feeders, consuming principally fish, but also garbage, small mammals, and insects (Fox et al., 1990). Black terns were most distinct from the other species, both in their chlorinated hydrocarbon levels and in their $\delta^{15} \mathrm{~N}$ abundances. Black terns are primarily insectivorous (Dunn and Agro, 1995). The lower trophic level of black terns compared to the other species, as inferred from stable nitrogen isotope analysis, coupled with the relatively low levels of chlorinated hydrocarbons in their eggs, suggests a possible link between diet and chlorinated hydrocarbon contaminant concentrations in eggs of these species on Great Slave Lake. However, we recognize that the relationship between trophic position, as inferred from stable isotope analysis, and tissue contaminant concentrations may be obscured by differences in the turnover rates of lipophilic contaminants and of protein and its associated elemental carbon and nitrogen. While $\delta^{15} \mathrm{~N}$ values in soft tissues of animals may reflect more recent diet because of the relatively rapid turnover rate of protein (Hobson and Clark, 1992), lipophilic chlorinated hydrocarbon contaminants turn over much more slowly (Norstrom et al., 1986; Clark et al., 1987). For migratory species, which may accumulate contaminants and nutrients at different locations and during different times of the year, it may be difficult to establish a relationship between contaminant concentrations in eggs and trophic level as inferred from stable isotope ratios in eggs.

\section{Selenium/Mercury Correlation}

This study found that selenium and mercury were correlated in the eggs of the four species, suggesting that these two elements co-accumulate in some birds' eggs. Sell (1977) noted that when selenium and mercury were simultaneously administered to chickens and quail, a higher proportion of the total mercury dose was deposited in eggs than when mercury alone was administered. While there are many examples of selenium and mercury co-accumulation in livers of wild birds (Norheim, 1987; Henny et al., 1991; Elliott et al., 1992), few such examples exist for eggs. Selenium and mercury were not correlated in the eggs of Franklin's gulls, black-crowned night herons, and 


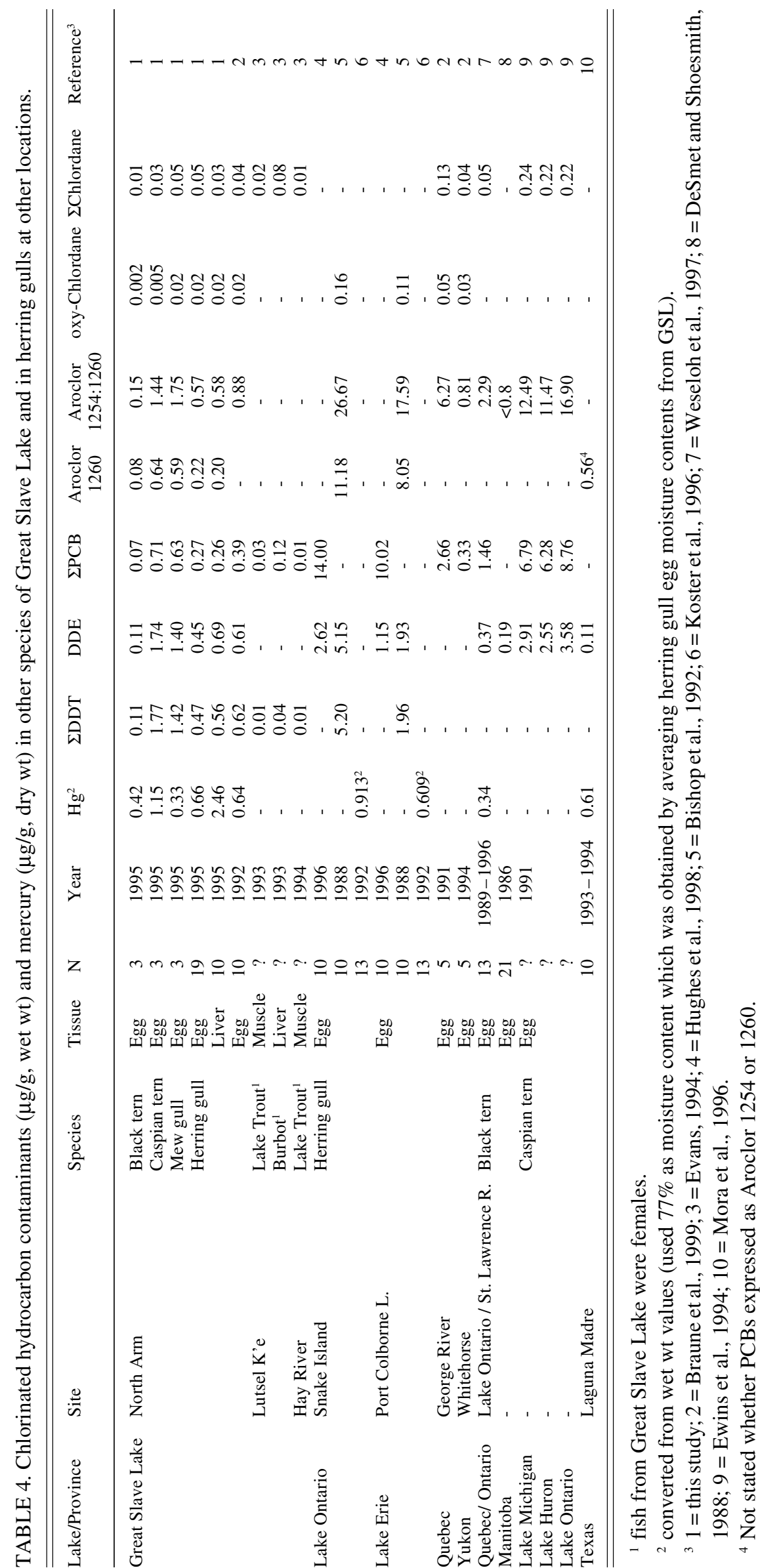

double-crested cormorants (Burger and Gochfeld, 1996), or in the eggs of herring gulls (Burger and Gochfeld, 1995). However, Goede and Wolterbeek (1994) reported a selenium-mercury correlation in the eggs of oystercatchers (Haematopus ostralegus).

In this study, the mean molar ratio of selenium to mercury was approximately 11:1. This is somewhat higher than the ratio of 4:1 in oystercatcher eggs (Goede and Wolterbeek, 1994), but it is similar to the ratios reported for eggs of three seabird species (Ohlendorf and Harrison, 1986) and for livers of ducks exposed to low levels of mercury (Ohlendorf et al., 1986, 1991). However, it differs from the approximate 1:1 ratio found in livers of species exposed to high concentrations of mercury (Kim et al., 1996; Scheuhammer et al., 1998).

\section{Comparison with Other Studies}

Chlorinated hydrocarbon contaminant concentrations in herring gull eggs at Great Slave Lake in 1995 differed little from those found in 1992 (Table 4). Nor did they differ from concentrations found in herring gull eggs from the Yukon Territory and northern Quebec (Table 4). However, herring gull eggs in this study had concentrations that were only 0.01 to 0.2 times as high as those in the Great Lakes (Table 4), signifying the relatively pristine nature of Great Slave Lake compared to the Great Lakes. Concentrations of chlorinated hydrocarbon contaminants in black terns in Great Slave Lake were similar to those found in Manitoba (DeSmet and Shoesmith, 1988) but were slightly lower than those found in southern Quebec and Ontario (Weseloh et al., 1997) (Table 4). For Caspian tern eggs, chlorinated hydrocarbon contaminant concentrations were much lower at Great Slave Lake than on the Great Lakes (Ewins et al., 1994) but were similar to those found by Mora (1996) in Texas (Table 4).

On a wet weight basis, fish tissue from Great Slave Lake had lower concentrations of chlorinated hydrocarbon contaminants than did herring gull eggs and livers (Table 4). However, direct comparison is difficult because different tissues were involved and because 
such comparisons are not adjusted for differences in lipid content of the tissues, an important consideration when comparing concentrations of lipophilic contaminants between species (Hebert and Keenleyside, 1995). On a lipid weight basis, Evans (1996) found that PCBs were from $0.32-0.46$ and sum of DDTs from $0.11-0.17 \mathrm{ppm}$ in burbot livers from Great Slave Lake. This compares with lipid weight-adjusted values of $11.3 \mathrm{ppm}$ for sum of DDTs and $4.6 \mathrm{ppm}$ for sum of PCBs in herring gull livers. Clearly, herring gulls have higher persistent chlorinated hydrocarbon contaminant concentrations than burbot, which is a high trophic level fish species in Great Slave Lake (Evans, 1996). This finding is similar to that reported for herring gulls and fish in the Great Lakes (Government of Canada, 1991). The trophic levels of burbot and herring gulls, as inferred from stable-nitrogen isotope ratios in muscle and lipid-free egg yolk, respectively (Evans, 1996; Hobson et al., 2000), were quite similar. Thus, differences in trophic level cannot account for the wide discrepancy in chlorinated hydrocarbon levels between the two species. While we cannot rule out the possibility of different metabolic efficiencies of the two species, this is not likely, because fish generally have a poorer capacity than birds for metabolizing such compounds as chlordanes and PCBs (Muir et al., 1988; Norstrom and Muir, 1994). A more probable explanation for the difference in contaminant levels between herring gulls and burbot on Great Slave Lake is that the former is homeothermic, resulting in higher energy requirements and thus higher dietary intake of contaminants (Braune and Norstrom, 1989). In addition, different sources of exposure to chlorinated hydrocarbons for burbot and herring gulls from Great Slave Lake may account for a fraction of the differences in their tissue contaminant concentrations. Burbot can only be exposed through the Great Slave Lake food chain, since they are year-round residents. However, herring gulls are migratory and probably experience the highest exposure to chlorinated hydrocarbon contaminants while in more polluted wintering and migration areas.

Mercury concentrations in herring gull and Caspian tern eggs from Great Slave Lake were similar to those in eggs of their conspecifics from other locales (Table 4).

Overall, we did not find evidence of spatial or seasonal variation in chlorinated hydrocarbon compounds in herring gulls on Great Slave Lake. The fact that spatial variation has been found for fish, aquatic insects, and sediments (Evans, 1996, 1997) suggests that herring gulls may not be appropriate biomonitors of such contaminants in Great Slave Lake. Mercury and selenium varied spatially and seasonally in herring gulls. The causes of spatial variation in these elements need to be determined. Stable isotope analysis indicated that chlorinated hydrocarbon levels in four species of colonial waterbirds on Great Slave Lake were related positively to their trophic levels.

\section{ACKNOWLEDGEMENTS}

We thank B. Wakeford and R. MacNeil of the National Wildlife Research Centre for facilitating tissue analyses. S. van Wilgenberg assisted during various stages of this study. We especially thank J. Keating for assisting with data management, analysis, and preparation of tables and figures. Organochlorine and metal analyses in eggs were performed by the Great Lakes Institute of the University of Windsor. E. Neuegebauer of the National Wildlife Research Centre performed metals analysis in livers. Garth Parry performed the stable isotope analyses at the University of Saskatchewan. The Canadian Wildlife Service (Yellowknife) assisted with funding and logistical support to Jacques Sirois. D. Kennedy and C. Mills facilitated major funding from the Department of Indian and Northern Affairs Canada, Yellowknife, Northwest Territories, through the Northern Contaminants Program. Additional funding was provided by Environment Canada.

\section{REFERENCES}

ANKLEY, G.T., NIEMI, G.J., LODGE, K.B., HALLETT, J.H., BEAVER, D.L., TILLITT, O.E., SCHWUITZ, T.R., GEISY, J.P., JONES, P.D., and HAGLEY, C. 1993. Uptake of planar polychlorinated biphenyls and 2,3,7,8-substituted polychlorinated dibenzofurans and dibenzo-p-dioxins by birds nesting in the lower Fox River and Green Bay Wisconsin USA. Archives of Environmental Contamination Toxicology 24:332-344.

ATWELL, L., HOBSON, K.A., and WELCH, H.E. 1998. Biomag-nification and bioaccumulation of mercury in an arctic marine food web: Insights from stable nitrogen isotope analysis. Canadian Journal of Fisheries and Aquatic Science 55:1114-1121.

BISHOP, C.A., WESELOH, D.V., BURGESS, N.M., STRUGER, J., NORSTROM, R.J., TURLE, R., and LOGAN, K.A. 1992. An atlas of contaminants in eggs of fish-eating colonial birds of the Great Lakes (1970-1988) Vol. 1. Canadian Wildlife Service Technical Report Series 152.

BOLTON, M., HOUSTON, D., and MONAGHAN, P. 1992. Nutritional constraints on egg formation in the lesser blackbacked gull: An experimental study. Journal of Animal Ecology 61:521-532.

BRAUNE, B.M., and GASKIN, D.E. 1987. Mercury levels in Bonaparte's gulls (Larus philadelphia) during autumn molt in the Quoddy region, New Brunswick, Canada. Archives of Environmental Contamination Toxicology 16:539-549.

BRAUNE, B.M., and NORSTROM, R.J. 1989. Dynamics of organochlorine compounds in herring gulls: III. Tissue distribution and bioaccumulation in Lake Ontario gulls. Environmental Toxicology and Chemistry 8:957-968.

BRAUNE, B.M., MALONE, B.J., BURGESS, N.M., ELLIOTT, J.E., GARRITY, N., HAWKINGS, J., HINES, J., MARSHALL, W.K., RODRIQUE, J., WAKEFORD, B., WAYLAND, M., WESELOH, D.V., and WHITEHEAD, P.E. 1999. Chemical residues in waterfowl and gamebirds harvested in Canada, 1987-95. Canadian Wildlife Service Technical Report Series No. 326. 
BROMAN, D., NAF, C., ROLFF, C., ZEBRIKS, Y., FRY, B., and HOBBIE, J. 1992. Using ratios of stable nitrogen isotopes to estimate bioaccumulation and flux of polychlorinated dibenzop-dioxins (PCDDs) and dibenzofurans (PCDFs) in two food chains from the northern Baltic. Environmental Toxicology and Chemistry 11:331-345.

BURGER, J., and GOCHFELD, M. 1995. Heavy metal and selenium concentrations in eggs of herring gulls (Larus argentatus): Temporal differences from 1989 to 1994. Archives of Environmental Contamination and Toxicology 29:192-197.

- 1996. Heavy metal and selenium levels in birds at Agassiz National Wildlife Refuge, Minnesota: Food chain differences. Environmental Monitoring and Assessment 43:267-282.

CLARK, T.P., NORSTROM, R.J., FOX, G.A., and WON, H.T. 1987. Dynamics of organochlorine compounds in herring gulls (Larus argentatus): II. A two-compartment model and data for ten compounds. Environmental Toxicology and Chemistry 6:547-559.

DeSMET, K.D., and SHOESMITH, M.W. 1988. Levels of organochlorines and PCBs in fish-eating and raptorial birds in Manitoba. Unpubl. report available at the Manitoba Department of Natural Resources, Wildlife Branch, Box 24, 200 Saulteaux Cres., Winnipeg, Manitoba R3J 3W3.

DUNN, E.H., and AGRO, D.J. 1995. Black tern. In: Poole, A., and Gill, F., eds. The birds of North America, No. 147. Philadelphia: The Academy of Natural Sciences, and Washington, D.C.: The American Ornithologists' Union.

EISLER, R. 1985. Selenium hazards to fish, wildlife and invertebrates: A synoptic review. United States Fish and Wildlife Service Biological Report 85(1.5).

ELLIOTT, J.E., SCHEUHAMMER, A.M., LEIGHTON, F.E., and PEARCE, P.A. 1992. Heavy metal and metallothionein concentrations in Atlantic Canadian seabirds. Archives of Environmental Contamination and Toxicology 22:63-73.

ELLIOTT, J.E., WILSON, L.K., LANGELIER, K.W., and NORSTROM, R.J. 1996. Bald eagle mortality and chlorinated hydrocarbon contaminants in livers from British Columbia, Canada, 1989-1994. Environmental Pollution 94:9-18.

EVANS, M.S. 1994. Biomagnification of persistent organic contaminants in Great Slave Lake. In: Murray, J.L., and Shearer, R.G., eds. Environmental Studies No. 72, Synopsis of Research Conducted under the 1993/94 Northern Contaminants Program. Ottawa: Indian and Northern Affairs Canada. 295-300.

- 1996. Biomagnification of persistent organic contaminants in Great Slave Lake. In: Murray, J.L., Shearer, R.G., and Han, S.L., eds. Environmental Studies No. 73, Synopsis of Research Conducted under the 1994/95 Northern Contaminants Program. Ottawa: Indian and Northern Affairs Canada. 215-220.

1997. Biomagnification of persistent organic contaminants in Great Slave Lake. In: Jensen, J., ed. Environmental Studies No. 74, Synopsis of Research Conducted under the 1995-1997 Northern Contaminants Program. Ottawa: Indian and Northern Affairs Canada. 173-178.

EWINS, P.J., WESELOH, D.V., NORSTROM, R.J., LEGIERSE, K., AUMEU, H.J., and LUDWIG, J.P. 1994. Caspian terns on the Great Lakes: Organochlorine contamination, reproduction, diet and population changes, 1972-91. Canadian Wildlife Service, Occasional Paper No. 85.

FOX, G.A., ALLAN, L.J., WESELOH, D.V., and MINEAU, P. 1990. The diet of herring gulls during the nesting period in Canadian Waters of the Great Lakes. Canadian Journal of Zoology 68:1075-1085.

GOEDE, A.A., and WOLTERBEEK, H.Th. 1994. Have high selenium concentrations their origin in mercury? The Science of the Total Environment 144:247-253.

GOVERNMENT OF CANADA. 1991. Toxic chemicals in the Great Lakes and associated effects: Synopsis. Ottawa: Environment Canada, Health Canada and Fisheries and Oceans Canada.

HEBERT, C.E., and KEENLEYSIDE, K.A. 1995. To normalize or not to normalize? Fat is the question. Environmental Toxicology and Chemistry 14:801-807.

HEBERT, C.E., SHUTT, J.L., and NORSTROM, R.J. 1997. Dietary changes cause temporal fluctuations in polychlorinated biphenyl levels in herring gull eggs from Lake Ontario. Environmental Science and Technology 31:1012-1017.

HEINZ, G.H. 1979. Methylmercury: Reproductive and behavioural effects on three generations of mallard ducks. Journal of Wildlife Management 43:394-401.

HEINZ, G.H., PENDLETON, G.W., KRYNITSKY, A.J., and GOLD, L.G. 1990. Selenium accumulation and elimination in mallards. Archives of Environmental Contamination Toxicology 19:374-379.

HENNY, C.J., BLUS, L.J., GROVE, R.A., and THOMPSON, S.P. 1991. Accumulation of trace elements and organochlorines by surf scoters wintering in the Pacific northwest. Northwestern Naturalist 72:43-60.

HOBSON, K.A., and CLARK, R.G. 1992. Assessing avian diets using stable isotopes I: Turnover of $13 \mathrm{C}$ in tissues. Condor 95:181- 188 .

HOBSON, K.A., SIROIS, J., and GLOUTNEY, M.L. 2000. Tracing nutrient allocations to reproduction with stable isotopes: A preliminary investigation using colonial waterbirds of Great Slave Lake. The Auk 117:760-774.

HUGHES, K.D., WESELOH, D.V., and BRAUNE, B.M. 1998. The ratio of DDE to PCB concentrations in Great Lakes herring gull eggs and its use in interpreting contaminants data. Journal of Great Lakes Research 24:12-31.

JARMAN, W.M., HOBSON, K.A., SYDEMAN, W.J., BACON, C.E., and McLAREN, E.B. 1996. Influence of trophic position and feeding location on contaminant levels in the Gulf of the Farallones food web revealed by stable isotope analysis. Environmental Science and Technology 30:654-660.

KIDD, K.A. 1998. Use of stable isotope ratios in freshwater and marine biomagnification studies. In: Rose, J., ed. Environmental toxicology: Current developments. Amsterdam: Gordon and Breach Science Publishers. 357-376.

KIDD, K.A., SCHINDLER, D.W., HESSLEIN, R.H., and MUIR, D.C.G. 1995. Correlation between stable nitrogen isotope ratios and concentrations of organochlorines in biota from a freshwater food web. Science of the Total Environment 16:1381-1390.

KIM, E.Y., SAEKI, K., TANABE, S., TANAKA, H., and TATSUKAWA, R. 1996. Specific accumulation of mercury and selenium in seabirds. Environmental Pollution 94:261 - 265. 
KOSTER, M.D., RYCKMAN, D.P., WESELOH, D.V.C., and STRUGER, J. 1996. Mercury levels in great lakes herring gull (Larus argentatus) eggs, 1972-1992. Environmental Pollution 93:261-270.

LEMLY, A.D. 1995. A protocol for aquatic hazard assessment of selenium. Ecotoxicology and Environmental Safety 32: $280-288$.

-1997. Environmental implications of excessive selenium: A review. Biomedical and Environmental Sciences 10: 415-435.

LOCKHART, W.L., WILKINSON, P., BILLECK, B.N., HUNT, R.V., WAGEMANN, R., and BRUNSKILL, G.J. 1995. Current and historical inputs of mercury to high-latitude lakes in Canada and to Hudson Bay. Water, Air and Soil Pollution 80:603-610.

MORA, M.A. 1996. Organochlorines and trace elements in four colonial waterbird species nesting in the lower Laguna Madre, Texas. Archives of Environmental Contamination and Toxicology 31:433-443.

MORRIS, R.D., and BLACK, J.E. 1980. Radiotelemetry and herring gull foraging patterns. Journal of Field Ornithology $51: 110-118$.

MUDROCH, A., JOSHI, S.R., SUTHERLAND, D., MUDROCH, P., and DICKSON, K.M. 1988. Geochemistry of sediments in the Back Bay and Yellowknife Bay of Great Slave Lake. Environmental Geology and Water Sciences 14:35-42.

MUIR, D.C.G., NORSTROM, R.J., and SIMON, M. 1988. Organochlorine contaminants in arctic marine food chains: Accumulation of specific PCB congeners and chlordane-related compounds. Environmental Science and Technology 22: $1071-1079$.

MUIR, D., BRAUNE, B., DEMARCH, B., NORSTROM, R., WAGEMANN, R., GAMBERG, M., POOLE, K., ADDISON, R., BRIGHT, D., DODD, M., DUSCHENCO, W., EAMER, J., EVANS, M., ELKIN, B., GRUNDY, S., HARGRAVE, B., HEBERT, C., JOHNSTONE, R., KIDD, K., KOENIG, B., LOCKHART, L., PAYNE, J., PEDDLE, J., and REIMER, K. 1997. Ecosystem uptake and effects. In: Jensen, J., Adare, K., and Shearer, R., eds. Canadian Arctic Contaminants Assessment Report. Ottawa: Indian and Northern Affairs Canada. 191 - 294.

NORHEIM, G. 1987. Levels and interactions of heavy metals in seabirds from Svalbard and the Antarctic. Environmental Pollution 47:83-94.

NORSTROM, R.J., and MUIR, D.C.G. 1994. Chlorinated hydrocarbon contaminants in arctic marine mammals. The Science of the Total Environment 154:107-128.

NORSTROM, R.J., CLARK, T.P., JEFFREY, D.A., WON, H.T., and GILMAN, A.P. 1986. Dynamics of organochlorine compounds in herring gulls (Larus argentatus): I. Distribution and clearance of [14C]DDE in free-living gulls (Larus argentatus). Environmental Toxicology and Chemistry 5: $41-48$.

NORSTROM, R.J., SIMON, M., MUIR, D.C.G., and SCHWEINSBURG, R. 1988. Organochlorine contaminants in Arctic marine food chains: Identification, geographical distribution and temporal trends in polar bears. Environmental Science and Technology 22:1063-1071.
OHLENDORF, H.M., and HARRISON, C.S. 1986. Mercury, selenium, cadmium and organochlorines in eggs of three Hawaiian seabird species. Environmental Pollution (Series B) 11:169-191.

OHLENDORF, H.M., LOWE, R.W., KELLY, P.R., and HARVEY, T.E. 1986. Selenium and heavy metals in San Francisco Bay diving ducks. Journal of Wildlife Management 50:64-71.

OHLENDORF, H.M., KILNESS, A.W., SIMMONS, J.L., STROUD, R.K., HOFFMAN, D.J., and MOORE, J.F. 1988. Selenium toxicosis in wild aquatic birds. Journal of Toxicology and Environmental Health 24:67-92.

OHLENDORF, H.M., MAROIS, K.C., LOWE, R.W., HARVEY, T.E., and KELLY,P.R. 1991. Trace elements and organochlorines in surf scoters from San Francisco Bay, 1985. Environmental Monitoring and Assessment 18:105-122.

PIEROTTI, R.J., and GOOD, T.P. 1994. Herring gull. In: Poole, A., and Gill, F., eds. The birds of North America, No. 124. Philadelphia: The Academy of Natural Sciences, and Washington, D.C.: The American Ornithologists' Union.

SAS INSTITUTE. 1988. SAS/Stat user's guide, release 6.03 edition. Cary, North Carolina: SAS Institute Inc.

SCHEUHAMMER, A.M. 1987. The chronic toxicity of aluminium, cadmium, mercury, and lead in birds: A review. Environmental Pollution 46:263-295.

SCHEUHAMMER, A.M., WONG, A.H.K., and BOND, D. 1998. Mercury and selenium accumulation in common loons (Gavia immer) and common mergansers (Mergus merganser) from eastern Canada. Environmental Toxicology and Chemistry 17:197-201.

SCHINDLER, D.W., KIDD, K.A., MUIR, D.C.G., and LOCKHART, W.L. 1995. The effects of ecosystem characteristics on contaminant distribution in northern freshwater lakes. Science of the Total Environment 16: $11-17$.

SELL, J.L. 1977. Comparative effects of selenium on metabolism of methylmercury by chicken and quail: Tissue distribution and transfer to eggs. Poultry Science 56:939-948.

SIROIS, J., FOURNIER, M., and KAY, M.F. 1995. The colonial waterbirds of Great Slave Lake, Northwest Territories: An annotated atlas. Canadian Wildlife Service, Occasional Paper No. 89.

SPIES, R.H., KRUGER, H., IRELAND, R., and RICE, D.W., Jr. 1989. Stable isotope ratios and contaminant concentrations in a sewage-distorted food web. Marine Ecology Progress Series 54:157-170.

TERRES, J.K. 1980. The Audubon Society encyclopedia of North American birds. New York: Alfred A. Knopf, Inc.

USEPA (UNITED STATES ENVIRONMENTAL PROTECTION AGENCY). 1998. Standard operating procedure 507: Determination of trace elements by inductively coupled plasma-mass spectrometry, method 200.8. Richmond, California: United States Environmental Protection Agency, Region 9 Laboratory.

VERMEER, K., and DEVITO, K. 1986. The nesting biology of mew gulls (Larus canus) on Kennedy Lake, British Columbia, Canada: Comparison with mew gulls in northern Europe. Colonial Waterbirds 9:95-103. 
WESELOH, D.V., EWINS, P.J., STRUGER, J., MINEAU, P., and NORSTROM, R.J. 1994. Geographical distribution of organochlorine contaminants and reproductive parameters in herring gulls on Lake Superior in 1983. Environmental Monitoring and Assessment 29:229-251.
WESELOH, D.V.C., RODRIGUE, J., BLOEKPOEL, H., and EWINS, P.J. 1997. Contaminant concentrations in eggs of black terns (Chlidonias niger) from southern Ontario and southern Quebec, 1989-1996. Colonial Waterbirds 20:604-616. 